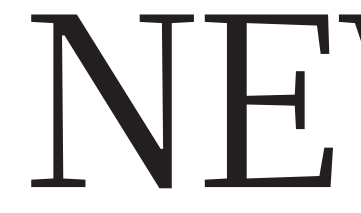

communitY One year after a massacre, a shattered biology department rebuilds $\mathbf{p . 1 5 0}$
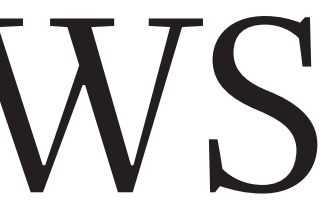

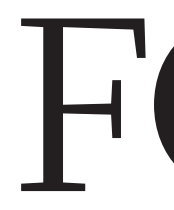

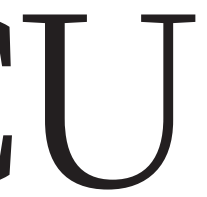

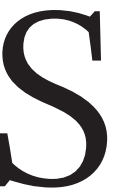

GENOMICS Single-molecule DNA sequencing proves to be fast but error-prone $\mathbf{p . 1 5 4}$
BIOMEDICINE One woman's fight against embryonic-stemcell research $\mathbf{p} .156$
EVOLUTION A battle over

the ancestry of animals hinges on a lowly worm p.161

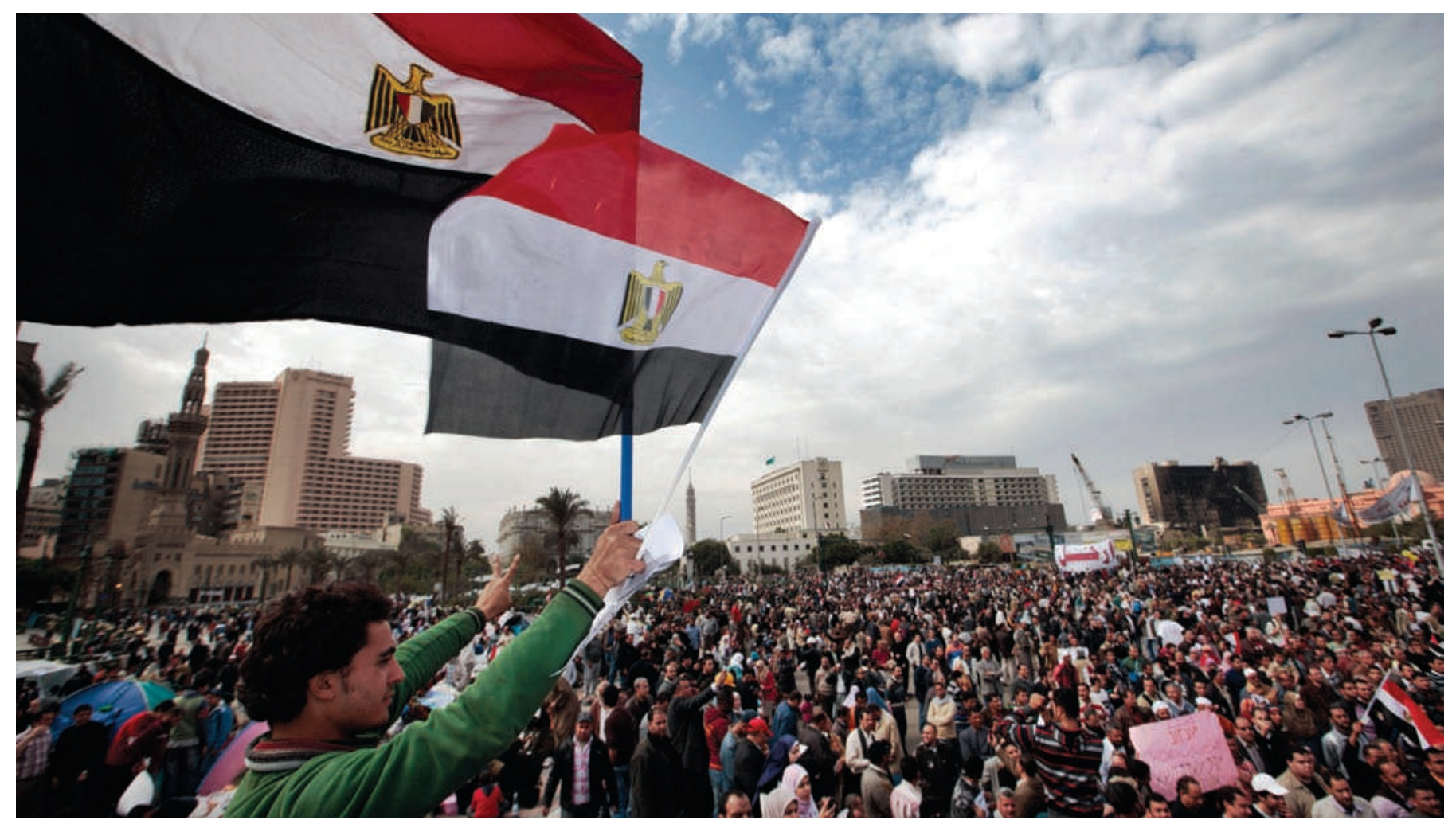

Thousands of anti-government protesters, including many students and academics, rally in Cairo's Tahrir Square.

\title{
Egypt's youth 'key to revival'
}

Country's future depends on democracy, education and research reform, say scientists.

\section{BY DECLAN BUTLER}

C 7 here is a pool of talent among the youth in Egypt that is unbelievable.

They are people who think creatively and critically, who are yearning for the freedom to express themselves, and many of them are those who are leading this revolution." Tarek Khalil, president and provost of the non-profit, independent Nile University in Cairo, is convinced that the country's Facebook generation represents the best chance in decades for the intellectual renaissance of a society that has been rendered moribund and impoverished by the military dictatorship of President Hosni Mubarak.
Other Egyptian researchers contacted by Nature share Khalil's views (see 'Scientists speak out'). They emphasize that, with the regime still in place two weeks after antiMubarak protests began on 25 January, the most urgent priorities are to halt the regime's crackdowns on protesters, and to ensure that the pro-democracy movement prevails. But in the long term, they say, Egypt's education and science systems must be completely overhauled to help address the root causes of its social and economic woes.

"The current outdated government simply lacks the mindset and vision to strategically support scientific research and lead an innovation-based economy that can compete globally," says Hassan Azzazy, a chemist at the non-profit, private American University in Cairo.

In an editorial in the International Herald Tribune last week, Ahmed Zewail, an Egyptian-born researcher at the California Institute of Technology in Pasadena, who won the 1999 Nobel chemistry prize, slammed the regime for presiding over a long deterioration in Egypt's education and research systems. Zewail returned to his home country last week to join a group of prominent Egyptian intellectuals who are drawing up plans, including constitutional reforms, to try to engineer a peaceful transition to democracy. Last week, Zewail - who is also one of six science envoys appointed by US President Barack Obama 


\section{COLLABORATION}

\section{Synchrotron faces setback}

The Synchrotron-light for Experimental Science and Applications in the Middle East (SESAME) project began in the late 1990s with a dual aim: to do research while building scientific ties in the troubled region. The plan is to install and upgrade a decommissioned German synchrotron at a facility in Alaan, Jordan, that scientists from partner nations will use for materials science and biological imaging.

But the project needs an extra US $\$ 35$ million to complete construction (on top of the $\$ 55$ million to $\$ 60$ million already committed), and it was counting on Egypt. Last year, Israel promised $\$ 5$ million, on the condition that other partner nations put in similar amounts. Egypt was among those expected to match the Israeli pledge at a SESAME meeting on 11 March. Hany Helal, the nation's science minister under President Hosni Mubarak, has been a staunch supporter of SESAME, but as Nature went to press, it was unclear how long Helal would remain in his post, or how a new government might view the project.

"It's obviously a bit worrying," says Chris Llewellyn Smith, a British physicist and president of SESAME's council. "But I think we'll come through it." Indeed, scientists across the Middle East are adamant that SESAME will proceed despite the unrest in Egypt, antigovernment protests in Jordan, and the murders of two members of the project's Iranian delegation (see Nature 468, 607; 2010). "It's very important that we keep it going, especially at times like this," says Zehra Sayers, a biophysicist at Sabanci University in Istanbul, Turkey, who chairs SESAME's science advisory committee.

Jordan, Iran, Turkey and the Palestinian Authority had all indicated that they might match Israel's offer, and Llewellyn Smith says that even if funding falls short, it could spur extra support from Western governments and major foundations.

Tarek Hussein, a physicist at Cairo University who has been encouraging his students to take part in the peaceful protests, says he is optimistic that any new government will remain committed to SESAME. There is reason for hope: Mohammed EIBaradei, a leading Egyptian opposition figure, was supportive of SESAME when he was director of the International Atomic Energy Agency in Vienna. Geoff Brumfiel See go.nature.com/pl2jjl for a longer version of this story.

\section{STAGNATING SCIENCE}

Science is poorly funded in Arab states. In 2007, they spent on average only $0.3 \%$ of their GDP on research, compared with a world average of $1.7 \%$ (1). Egypt leads the region on research publications, but its world share has remained flat for more than a decade (2).

Spending on research and development (\% of GDP)

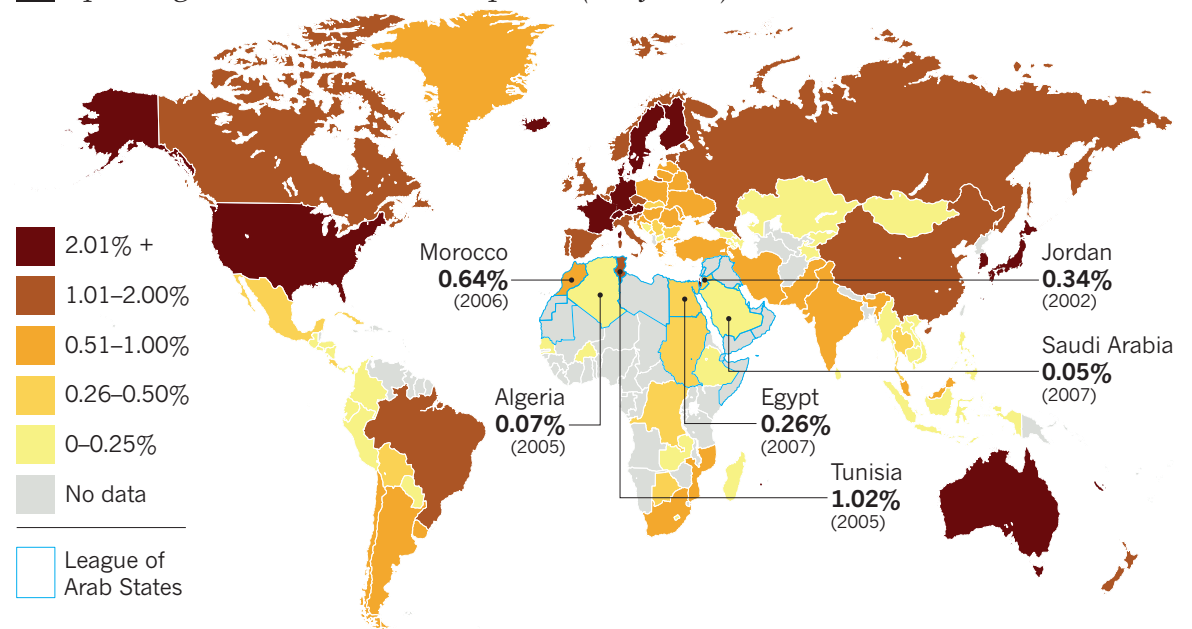

Share of science publications

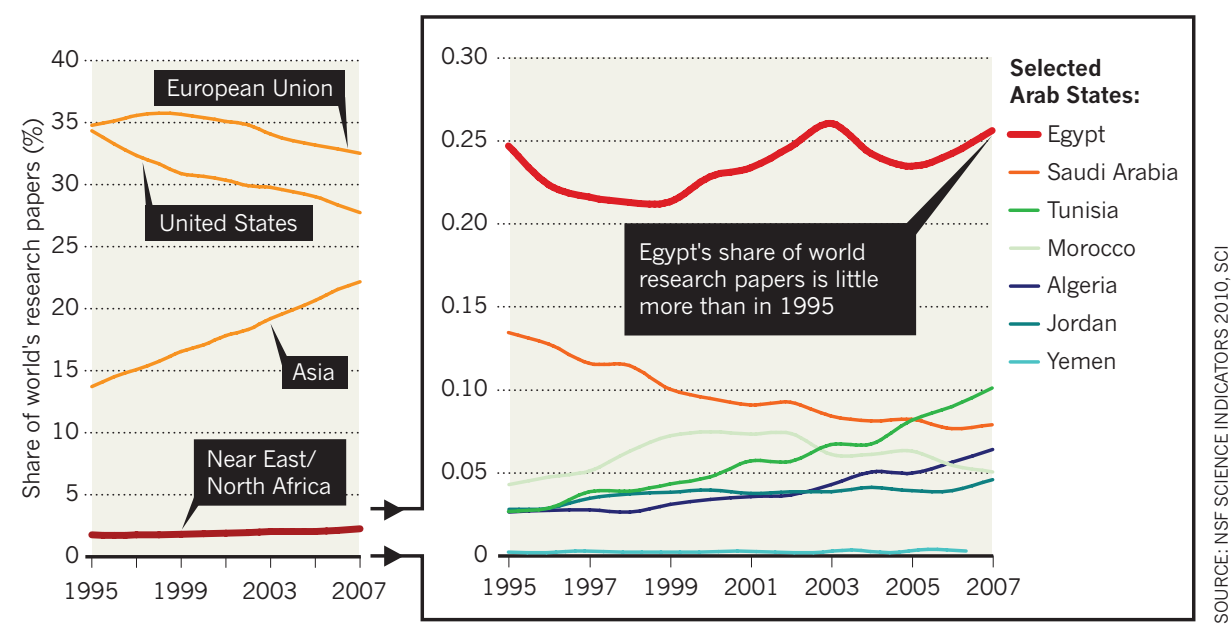

$\checkmark$ to Muslim-majority countries - called on Mubarak to step aside, to help Egypt make a fresh start.

Zewail's assessment of Egypt's decrepit education and research systems is accurate, says Khalil. Intake at the public universities - which offer students free tuition has expanded vastly since the 1960s, in line with the country's rapidly growing population. But budgets have remained flat, salaries have stagnated, and training of teachers and lecturers has been neglected, he explains. "Egyptian public universities currently do not foster productivity or innovation," adds Azzazy. "They are simply assembly lines that produce thousands of unskilled graduates every year."

As is the case in other authoritarian Arab regimes (see Nature 469, 453-454; 2011), political patronage and nepotism are rife in senior university appointments. The suppression of human rights, and the poor conditions for science, have also led to a brain drain to the West, and more recently to Gulf states that are investing in research. According to the Science Citation Index, Egypt produced 5,140 scientific papers in 2010. Harvard University in Cambridge, Massachusetts, published twice that number alone.

Egypt's research has also been plagued by a lack of funding, with research spending amounting to just $0.2-0.3 \%$ of the country's gross domestic product (GDP; see graphic). "Mubarak wasn't interested in science; he didn't have the vision or the ability to understand what development takes," says Khalil. "Hopefully, we

\section{$\rightarrow$ NATURE.COM} For interviews with Hassan Azzazy and Tarek Khalil, see: go.nature.com/nvzvbk and go.nature.com/ kuonbt will get an Egypt that will appreciate research and education. This has to be a top priority for the country."

Fostering international collaborations could be a key factor in achieving 


\section{ANTIQUITIES}

\section{The fight to protect an ancient heritage}

Images of Molotov cocktails thrown towards the Egyptian Museum in Cairo by supporters of President Hosni Mubarak last week horrified archaeologists, who feared for the world's largest collection of Egyptian artefacts. Vandalism on 28 January had already damaged about 70 pieces there.

Such attacks highlight the predicament of protecting cultural heritage during conflicts, while also dealing with a more important priority: preventing loss of life. Under the 1954 Convention for the Protection of Cultural Property in the Event of Armed Conflict, countries pledge to create inventories of heritage areas, and to set up military units with archaeological expertise to protect sites. Egypt has signed the treaty, but the unrest caught its military off guard - protesters and citizens took the lead in protecting museums and sites.

Zahi Hawass, the newly appointed Egyptian minister of antiquities, said last week that the army was now protecting all 24 national museums and all major archaeological sites. But some fear that may not be enough. "Egypt's ancient heritage is so rich that the whole country is basically one large open-air museum. It would be impossible to station a soldier at the door of each and every tomb," says Margaret Maitland, an Egyptologist at the University of Oxford, UK, who has been writing about the incidents on her blog, The Eloquent Peasant.

Frank Rühli, co-head of the Swiss Mummy Project at the University of Zurich, hopes Egypt will ask external experts to assess the

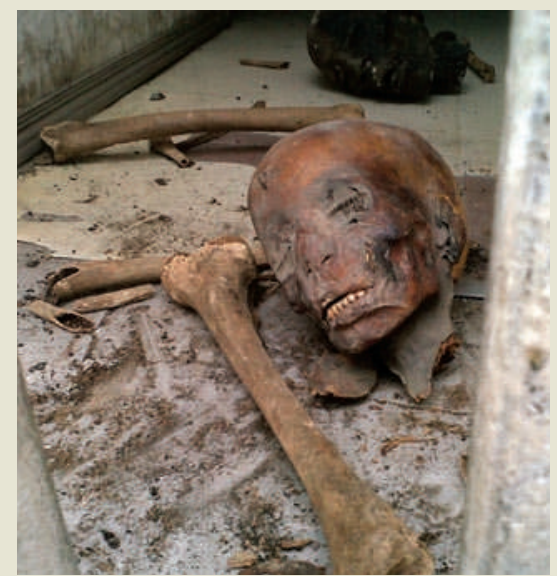

A damaged mummy at the Egyptian Museum.

damage and decide on restoration measures, as was done in 2003 during the Iraq War by the United Nations Educational, Scientific and Cultural Organization. Researchers have asked law-enforcement agencies and art dealers around the world to look out for stolen antiquities.

Yet Egypt's heritage is understandably not foremost in the minds of those facing the violent crackdown. "We are all very concerned about the Egyptian Museum, but please what we need first is to restore order and save the Egyptian people," said a member of the Restore + Save the Egyptian Museum! Facebook page last week, after bloody clashes in Cairo's Tahrir Square. D.B. See go.nature.com/v4fbui for a longer version of this story. that. But the unrest has already led to uncertainty about Egypt's role in the SESAME synchrotron project in Jordan (see 'Synchrotron faces setback'), and looting at the Egyptian Museum in Cairo and other cultural-heritage sites has raised archaeologists' fears over the security of the country's antiquities and possible threats to research (see 'The fight to protect an ancient heritage').

But it is the denial of freedoms under the Mubarak regime that Egyptian scientists see as the most serious obstacle to progress. The stifling effect that this has had on creativity is "detrimental to creating a knowledge society; people dare not think out-of-the-box", says Farouk El-Baz, an Egyptian-born geologist at Boston University in Massachusetts.

One result, says Khalil, is that the educational culture in Egypt has become based on rote learning of existing knowledge and dogma, and doesn't allow for debate or creative thinking. "The whole concept of creativity and entrepreneurship is alien to the existing system," he says.

"Building science is not just a question of money and projects, it is also about a whole climate of research, of freedom of enquiry, freedom of expression, education, the ability to question," adds Ismail Serageldin, director of the Library of Alexandria. That the country's youth is now standing up for these values gives reason for hope, he says.

Despite the repression and stagnation in Egypt, Serageldin says, profound changes have been brewing for years. Empowered by discussions using the Internet, the young have come to find freedom of expression, and other rights, "so natural that it's like breathing - they can't accept anything else", he says.

"What Egypt most needs now to develop itself is to unleash the energy of its youth and its population," adds El-Baz. "This regime must leave, and let a younger generation take power."

\section{Scientists speak out}

Several senior academics took to the streets of Cairo last week to join the anti-government protests. They spoke to Nature Middle East about the state of science in Egypt and their hopes for the future.

\section{Mahmoud Saleh}

\section{Chemist, Cairo University}

There is no proper scientific research in Egypt. This regime has killed the talents and capabilities of the Egyptian people, whether scientific, social or political.

Spending on scientific research was minimal. A whole generation of scientists moved overseas to continue their pursuit of knowledge to help this country. But when they returned they found that all paths to achieve this were blocked. This is part of the reason behind us revolting.

We hope there will be a new, smarter government that respects the role of science and technology in the development of society.

\section{Hani Dewedar}

\section{Astronomer, Cairo University}

University education needs serious reform. The government needs to invest and provide a good environment for education to maximize the student experience.

We want to link universities to the community and to industry. This would be of great benefit to the students and the education system as well as society in general.

\section{Tahir Ahmed Yehia}

Agricultural scientist, Cairo University Scientists need tools: funding, proper equipment, good budgets for universities and laboratories. Sadly, however, these tools are lacking in Egypt and it is apparent that the current regime does not believe in scientific research.

In this protest there is no distinction between university professors and students. We've all come out as Egyptians. There is no distinct age or social standard, we all have the same demands - a regime change that improves conditions for us all and tackles the problems we have faced for so long.

INTERVIEWS BY MOHAMMED YAHIA See go.nature.com/gbd12q for longer versions of these interviews. 